\title{
Nano-fibrous scaffolding architecture selectively enhances protein adsorption contributing to cell attachment
}

\author{
Kyung Mi Woo, ${ }^{1}$ Victor J. Chen, ${ }^{2}$ Peter X. $\mathrm{Ma}^{1-3}$ \\ ${ }^{1}$ Department of Biologic and Materials Sciences, 1011 North University Avenue, Room 2211, The University of \\ Michigan, Ann Arbor, Michigan 48109-1078 \\ ${ }^{2}$ Department of Biomedical Engineering, The University of Michigan, Ann Arbor, Michigan \\ ${ }^{3}$ Macromolecular Science and Engineering Center, University of Michigan, Ann Arbor, Michigan
}

Received 21 August 2002; revised 14 February 2003; accepted 12 March 2003

\begin{abstract}
Tissue engineering aims at resolving problems such as donor shortage and immune rejection faced by transplantation. Scaffolds (artificial extracellular matrices) have critical roles in tissue engineering. Recently, we developed nano-fibrous poly(L-lactic acid) scaffolds under the hypothesis that synthetic nano-fibrous scaffolding, mimicking the structure of natural collagen fibers, could create a more favorable microenvironment for cells. This is the first report that the nano-fibrous architecture built in three-dimensional scaffolds improved the features of protein adsorption, which mediates cell interactions with scaffolds. Scaffolds with nano-fibrous pore walls adsorbed four times more serum proteins than scaffolds with solid pore walls. More interest-
\end{abstract}

ingly, the nano-fibrous architecture selectively enhanced protein adsorption including fibronectin and vitronectin, even though both scaffolds were made from the same poly(L-lactic acid) material. Furthermore, nano-fibrous scaffolds also allowed $>1.7$ times of osteoblastic cell attachment than scaffolds with solid pore walls. These results demonstrate that the biomimetic nano-fibrous architecture serves as superior scaffolding for tissue engineering. (C) 2003 Wiley Periodicals, Inc. J Biomed Mater Res 67A: 531-537, 2003

Key words: nano; fiber; scaffold; protein; tissue engineering; polymer; adsorption

\section{INTRODUCTION}

Tissue engineering is a promising approach to resolve the problems faced by transplantation including the shortage of donor tissues (organs) and immune rejection. ${ }^{1,2}$ In tissue engineering, the scaffold [artificial extracellular matrix (ECM)] has critical roles in supporting cell adhesion, migration, proliferation, differentiated function, neo tissue generation, and its three-dimensional (3D) organization. The scaffold is a 3D substrate for cells, serves as a template for tissue regeneration, and should finally be replaced by the cell-produced ECM. To perform these roles, a scaffold should provide a good 3D microenvironment for cell attachment, proliferation, and differentiation. Biodegradable polymers are attractive candidates because

Correspondence to: P. X. Ma; e-mail: mapx@umich.edu Contract grant sponsor: University of Michigan

Contract grant sponsor: Whitaker Foundation

Contract grant sponsor: Korea Science \& Engineering Foundation

(C) 2003 Wiley Periodicals, Inc. they degrade after fulfilling the scaffolding function, eventually leaving nothing foreign in the body.

Collagen is the major component of mammalian connective tissues. It is found in every major tissue that requires strength and flexibility such as bone and skin. Collagen proteins, by definition, are characterized by unique triple-helix formation extending over a large portion of the molecules. So far, approximately 25 distinct collagen alpha chains have been identified, each encoded by a separate gene. ${ }^{3}$ The most abundant is type I. The feature of type I collagen molecule is its long, stiff, triple-stranded helical structure, in which three collagen polypeptide chains are wound around one another in a ropelike superhelix. After being secreted into extracellular space, these collagen molecules assemble into higher-order polymers called collagen fibrils, and the fibrils are finally assembled into collagen fibers with diameters ranging from 50 to 500 $\mathrm{nm}$. Being a major ECM component, type I collagen has been used extensively in the formulation of biomedical materials, especially for soft tissue repair. ${ }^{4}$ Because of its phylogenetically well-conserved primary sequence and its helical structure, collagen is relatively bioinert. ${ }^{5}$ The use of collagen as a scaffold- 
ing material, however, still remains to be developed to overcome the concern of pathogen transmission, the difficulties in handling, and less control over the mechanical properties, biodegradability, and batch-to-batch consistency of natural materials from biological sources. ${ }^{6}$

One of the major goals of tissue engineering is to generate tissues/organs mimicking their natural counterparts. One of the best approaches toward "ideal" scaffold design is the biomimetic methodology. The fiber structure of collagen has long been noticed to be important for cell attachment, proliferation, and differentiated function in tissue culture. ${ }^{7-9}$ We hypothesized that synthetic nano-fibrous architecture could mimic the ECM microenvironment. Under this hypothesis, nano-fibrous materials were developed of synthetic biodegradable polymers in our laboratory using a phase-separation technique, to mimic the architecture of collagen. ${ }^{6}$ Moreover, 3D macroporous architectures have been built in the nano-fibrous matrices to improve the cell seeding, distribution, and mass transport. ${ }^{10}$ In this work, we report nano-fibrous poly(L-lactic acid) (PLLA) scaffolds with interconnected spherical macropores for tissue engineering applications.

Cell attachment, migration, and growth on the polymer surfaces are believed to be mediated by proteins, either adsorbed from serum proteins or secreted by the cells. To evaluate one of the biological properties of the scaffolds, the protein adsorption to these nanofibrous PLLA scaffolds was examined. Cell attachment in relation to the scaffold architecture was also evaluated.

\section{MATERIALS AND METHODS}

\section{Construction of PLLA nano-fibrous polymer scaffolds}

A $12.5 \%(\mathrm{wt} / \mathrm{v})$ solution of PLLA in a 1:1 (v/v) mixture of dioxane and pyridine was prepared. Paraffin spheres $(0.40 \pm$ $0.01 \mathrm{~g}$, diameter $=250-420 \mu \mathrm{m}$ ) were added to Teflon molds (cylindrical vial with a diameter of $18 \mathrm{~mm}$ ), and the top surface of the paraffin was leveled..$^{11}$ The molds were then heat-treated at $37^{\circ} \mathrm{C}$ for $45 \mathrm{~min}$ at which time they were removed and cooled to room temperature. Prepared polymer solution $(0.32 \mathrm{~mL})$ was cast onto each paraffin sphere assembly dropwise and vacuum-treated quickly in a heated vacuum oven $\left(250 \mathrm{mmHg}, \sim 37^{\circ} \mathrm{C}\right)$ to remove air trapped inside the paraffin sphere assemblies. Vacuum treatment in the heated oven was done as quickly as possible to avoid further bonding of the paraffin spheres. The polymer solution (in the paraffin assembly) was phase-separated at $-70^{\circ} \mathrm{C}$ overnight. Then, the vials containing the polymer/ paraffin composite were immersed into cold hexane for 2 days $\left(-18^{\circ} \mathrm{C}\right)$ to extract the solvent. Next, the composites were removed from the vials and were cut to the correct height $(1 \mathrm{~mm})$ and diameter $(7.2 \mathrm{~mm})$. The composites were then placed into room temperature hexane to extract the remaining solvent and to leach the paraffin from the composite. Samples were kept in room temperature hexane for 2 days, changing the hexane three times a day. Hexane was then exchanged with cyclohexane. The polymer scaffolds were removed from the cyclohexane, and were frozen $\left(-70^{\circ} \mathrm{C}\right)$ for at least $6 \mathrm{~h}$. The frozen scaffolds were then lyophilized $(<30 \mathrm{mmHg})$ at $-70^{\circ} \mathrm{C}$ for 7 days, at $-5^{\circ}$ to $-10^{\circ} \mathrm{C}$ for 2 days, and dried under the same vacuum pressure at room temperature for 2 days.

\section{Construction of PLLA solid-walled scaffolds}

For PLLA solid-walled scaffolds, a $12.5 \%(\mathrm{wt} / \mathrm{v})$ solution of PLLA in dioxane was prepared. The paraffin sphere mold preparation and the polymer casting procedure were performed in the same way as for the nano-fibrous scaffolds. After polymer casting, the polymer/paraffin composites were dried under low vacuum overnight $(\approx 340 \mathrm{mmHg})$, and under high vacuum ( $<30 \mathrm{mmHg}$ ) for 4 days. Samples were removed from the vials and cut to the correct height (1 $\mathrm{mm}$ ) and diameter $(7.2 \mathrm{~mm})$. Paraffin leaching and lyophilizing procedures were performed in the same manner as for nano-fibrous scaffolds.

\section{Protein adsorption to scaffolds}

The scaffolds were placed in the protein solutions after they were completely wetted. To wet the scaffolds, they were soaked in $100 \%$ ethanol for an hour and in phosphatebuffered saline (PBS) (Gibco BRL, Grand Island, NY) for 30 min twice. During the wetting procedure, they were placed in a vacuum container to remove air bubbles in the scaffolds. The scaffolds were then incubated in PBS overnight on a shaker ( $25 \mathrm{rpm})$. The wetted scaffolds were incubated in $25 \%$ human serum, $100 \mu \mathrm{g} / \mathrm{mL}$ fibronectin (Sigma, St. Louis, $\mathrm{MO})$, vitronectin (Biosource International, Carmarillo, CA), laminin (Sigma), or bovine serum albumin solutions in PBS for $4 \mathrm{~h}$ on the shaker ( $25 \mathrm{rpm}$ ). After the $4 \mathrm{~h}$ of incubation, the scaffold was removed from the protein solution, tapped on the Whatman paper, and then transferred to a microtube. The scaffold was washed with $600 \mu \mathrm{L}$ of PBS under gentle agitation for $5 \mathrm{~min}$. The washing solution was then discarded and $600 \mu \mathrm{L}$ of fresh PBS was replaced to wash again. A total of three washings was conducted to remove free and loosely adsorbed proteins (there was a negligible amount of proteins in the third washing solution). The remaining proteins (adsorbed) on the scaffold were recovered by incubation in $1 \%$ sodium dodecyl sulfate (SDS) solution for $1 \mathrm{~h}$ after homogenization. The procedures were repeated two more times and the three solutions were pooled in one tube. The total amount of protein was measured using MicroBCA assay (Pierce, Rockford, IL).

\section{Western blot analysis for serum fibronectin and vitronectin adsorbed to the scaffolds}

The recovered serum protein samples $(25 \mu \mathrm{L}$ of a total of $400 \mu \mathrm{L}$ ) were subject to fractionation through $4-12 \%$ SDS- 
polyacrylamide gel electrophoresis (PAGE). The fractionated proteins were transferred to a PVDF membrane (Sigma). The blots were washed with TBST (10 mM Tris$\mathrm{HCl}, 150 \mathrm{mM} \mathrm{NaCl}, 0.05 \%$ Tween-20, pH 8.0), and blocked with Blotto (5\% nonfat milk in TBST) at room temperature for $1 \mathrm{~h}$. The blots were incubated in anti-human fibronectin or anti-human vitronectin polyclonal antibodies (Santa Cruz Biotechnology, Santa Cruz, CA) at room temperature for $1 \mathrm{~h}$. After washing with TBST, the blots were incubated in antigoat immunoglobulin G-horseradish peroxidase-conjugated antibody (Sigma), and then in chemiluminescence reagent (SuperSignal West Dura; Pierce). The relative densities of the protein bands were analyzed with QualityOne (Biorad).

\section{Attachment of MC3T3-E1 cells to the scaffolds}

The MC3T3-E1 osteoblasts were cultured in ascorbic acidfree alpha-Eagle's minimum essential medium (Quality Biological, Gaithersburg, MD) supplemented with $10 \%$ fetal bovine serum (Gibco BRL), $50 \mathrm{U} / \mathrm{mL}$ penicillin, and $50 \mu \mathrm{g} / \mathrm{mL}$ streptomycin in a humidified incubator at $37^{\circ} \mathrm{C}$ with a $\mathrm{CO}_{2} /$ air ratio of 5:95. The sterilized solid-walled and nano-fibrous PLLA scaffolds were soaked in ethanol for $1 \mathrm{~h}$ and then exchanged with PBS three times (30 min each). The scaffolds were then washed with the alpha-Eagle's minimum essential medium containing $10 \%$ fetal bovine serum two times ( $2 \mathrm{~h}$ each). Two million cells were seeded on each scaffold. The cell-scaffold constructs were cultured on an orbital shaker (75 rpm). After $24 \mathrm{~h}$, the cultured osteoblast-scaffold constructs were washed with PBS twice (5 min each), and homogenized with tissue tearer for $1 \mathrm{~min}$ at 20,000 rpm. The DNA content was determined using Hoechst 33258.

\section{Statistical analysis}

Student $t$ test was performed, and the difference was regarded as significant if the $p$ value was $<0.05$.

\section{RESULTS}

\section{Construction of nano-fibrous and solid-walled PLLA scaffolds}

Three-dimensional porous PLLA scaffolds (height $=1 \mathrm{~mm}$, diameter $=7.2 \mathrm{~mm}$ ) were created with interconnected spherical pores (diameter $=250-$ $420 \mu \mathrm{m})$. In these studies, the effects of pore wall architectures were compared. Scaffolds having pore walls with nano-fibrous architectures (diameter of fibers $\approx 50-500 \mathrm{~nm}$ ) were created by thermally induced phase separation [Fig. 1(a,b)], and scaffolds having solid pore walls were created by solvent casting-evaporation techniques as previously published ${ }^{11}$ [Fig. $1(\mathrm{c}, \mathrm{d})]$. Both the nano-fibrous and solid-walled scaf- folds had similar porosities of $96 \%$ (calculated from scaffold mass, dimensions, and crystallinity using a published protocol ${ }^{6}$ ) and macro-porous structures.

\section{Protein adsorption from serum to the scaffolds}

Both scaffolds were incubated in human or bovine serum after they were completely wetted. The nanofibrous scaffold adsorbed 4.2-fold greater amount of human serum proteins than the solid-walled scaffold [Fig. 2(A)]. Consistent results were obtained from bovine serum. SDS-PAGE analysis corroborated that greater amounts of serum proteins were adsorbed to the nanofibrous scaffold [Fig. 2(B)]. Moreover, the profile of adsorbed serum proteins to the nano-fibrous scaffold was different from that to the solid-walled scaffold. Whereas the intensities of the protein with an approximate size of $150 \mathrm{kDa}$ (arrow) adsorbed to both scaffolds similarly, the proteins with approximate sizes of 120,45 , or $40 \mathrm{kDa}$ (arrowheads) exclusively adsorbed onto the nano-fibrous scaffold. Based on the measurements of band intensities of proteins, the amounts of proteins adsorbed to nano-fibrous scaffolds were 0.57-13.35 times those of corresponding proteins (bands) in control serum, whereas the amounts of proteins adsorbed to solidwalled scaffolds were $0.24-0.79$ times those of corresponding proteins in the control serum [Table I and Fig. 2(C)]. The ratios of adsorbed amounts of proteins on nano-fibrous scaffolds to those on solid-wall scaffolds were always $>1.0$ and varied drastically with the proteins (Table I). Considering that both scaffolds were made of the same PLLA material, it was surprising that nano-fibrous architecture alone could alter the profile of protein adsorption from serum and showed selectivity. More interestingly, Western blot analyses showed that the nano-fibrous scaffolds adsorbed large amounts of fibronectin and vitronectin from serum, but these celladhesion proteins were barely detected on the solidwalled scaffolds (Fig. 3). These findings suggested that nano-fibrous scaffolds might have certain features enhancing specific protein-affinity and binding strength.

\section{Adsorption of ECM proteins to the scaffolds}

Cell-ECM interactions participate directly in mediating cell adhesion, migration, growth, differentiation, and apoptosis. ${ }^{12}$ Adsorption of a few ECM proteins to nano-fibrous and solid-walled scaffolds was analyzed to understand the cell behavior on these different scaffolds. Prewetted scaffolds were incubated in fibronectin, vitronectin, laminin, or bovine serum albumin solution. These proteins were adsorbed to the nanofibrous scaffolds 2.6-3.9 times higher than to the solid- 


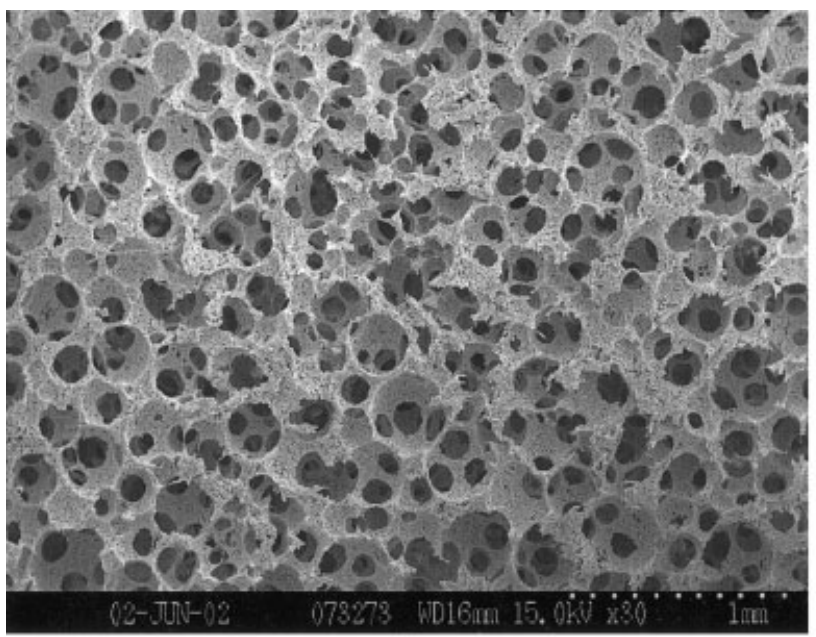

(a)

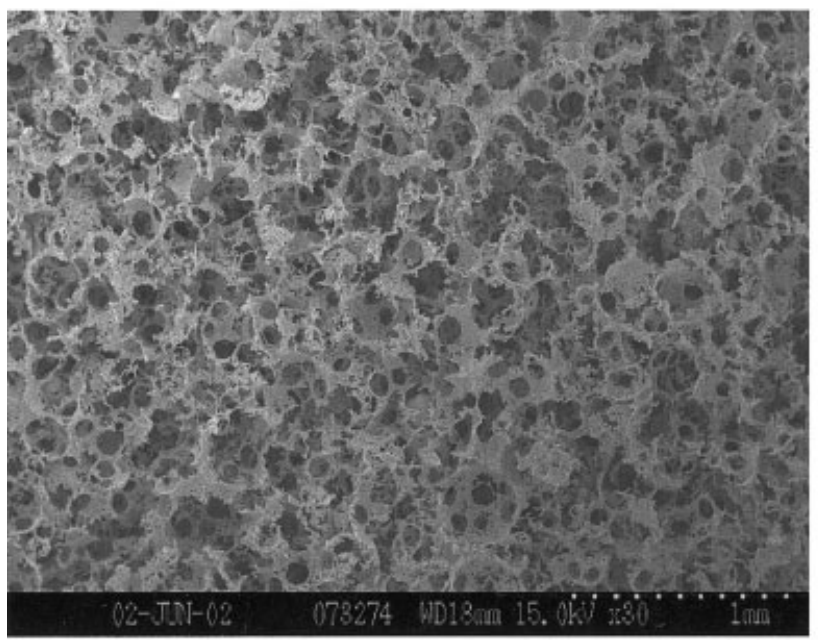

(c)

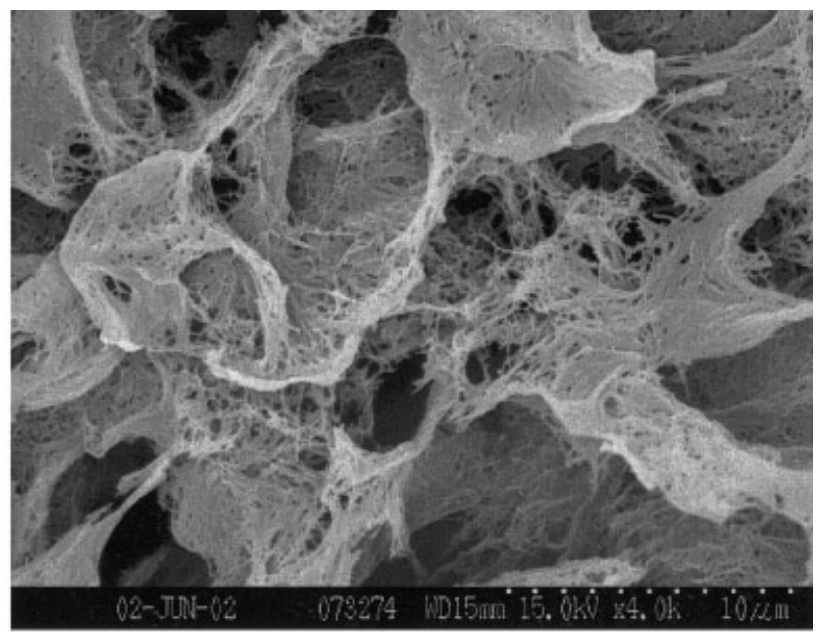

(b)

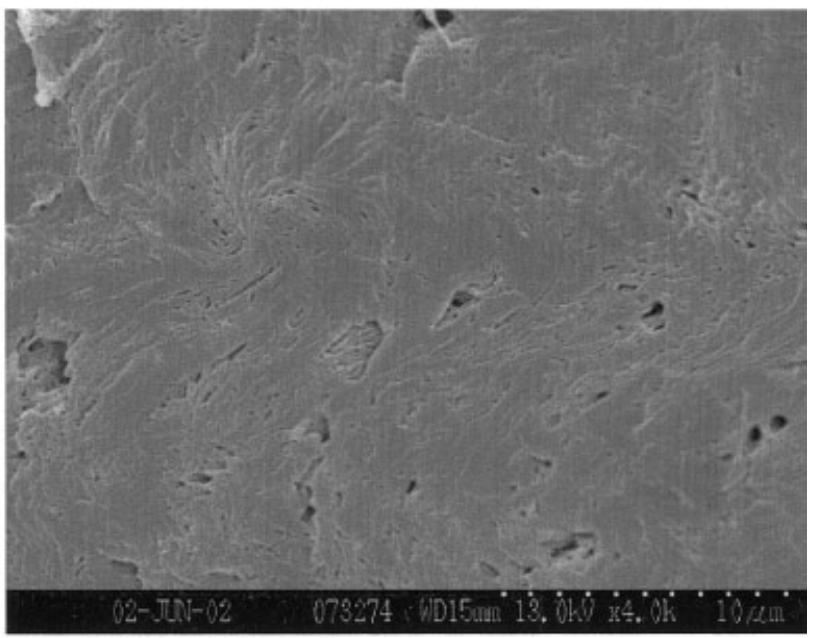

(d)

Figure 1. Scanning electron photomicrographs of nano-fibrous $(a, b)$ and solid-walled $(c, d)$ scaffolds. Original magnification, $\times 30(a, c), \times 4000(b, d)$.

walled scaffolds (Fig. 4). The amounts of different ECM proteins adsorbed to the nano-fibrous scaffolds were statistically different among most of the ECM proteins studied (fibronectin, vitronectin, laminin, and albumin), with an exception that adsorbed amounts of vitronectin and albumin were similar. In contrast, the amounts of these proteins adsorbed to the solidwalled scaffolds were not statistically different. These features were consistent with the findings from serum protein adsorption, suggesting that nano-fibrous scaffolds have higher specificity for protein adsorption.

\section{Cell attachment to the scaffolds}

In tissue engineering, cell adhesion to a substrate is critical because adhesion precedes other events such as cell spreading, cell migration, and often, differentiated cell function. The nano-scaffolds were evaluated for cell attachment. After $24 \mathrm{~h}$ of cell seeding on scaffolds pretreated in fetal bovine serum, the amount of DNAs within a nano-fibrous scaffold was 1.7 -fold of that within a solid-walled scaffold (Fig. 5). Considering that both scaffolds (nano-fibrous and solid-walled) have the same macropore structure (interconnected spherical network) for cell accommodation, this finding suggests that nano-fibrous architecture provides a more favorable environment for cell attachment.

\section{DISCUSSION}

Tissues are made up of cells and ECM. During tissue development, ECM is secreted and organized locally by the cells. The ECM serves as a structural support for cells in the tissue. Also, cell-ECM interactions can directly control cell behavior such as attachment, migration, proliferation, differentiation, and ap- 
A

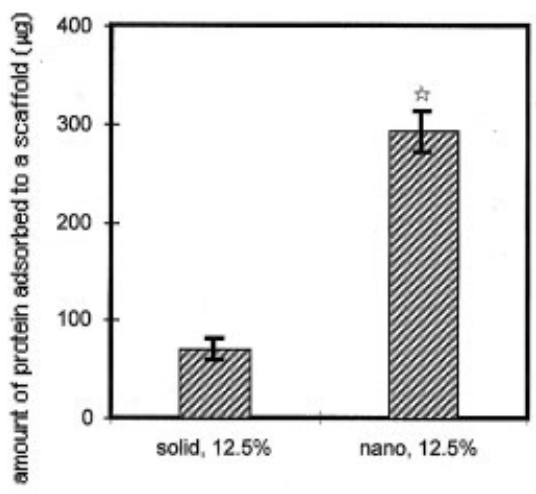

B

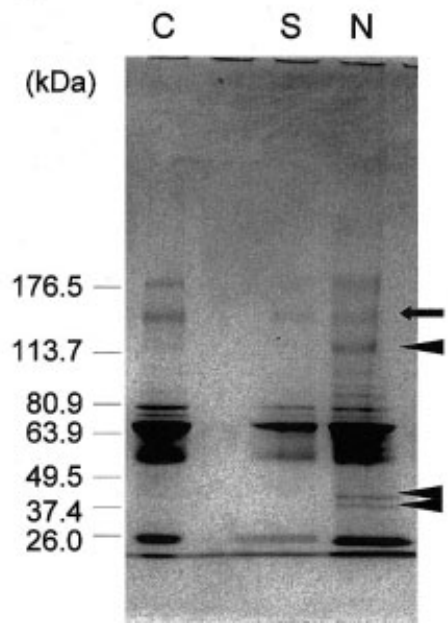

C

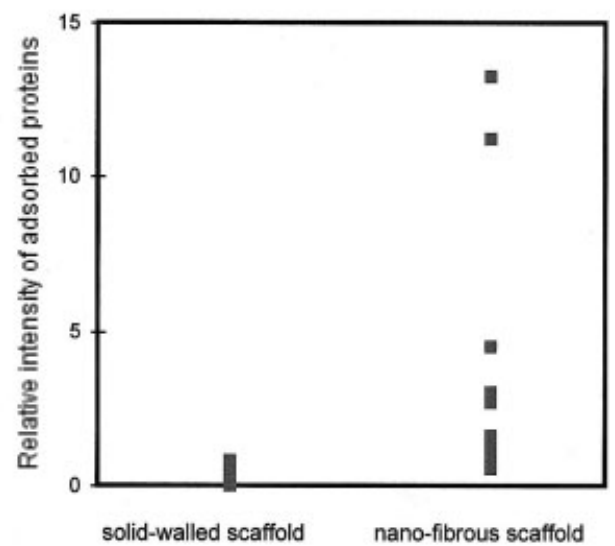

Figure 2. (A) Amount of adsorbed serum proteins to the scaffolds. *Significantly different from solid-walled scaffolds, $p<$ $0.05, n=4$. (B) $4-12 \%$ polyacrylamide gels stained with Coomassie blue. Lane C, bovine serum proteins; lane S, adsorbed bovine serum proteins to the solid-walled scaffold; lane $\mathrm{N}$, adsorbed bovine serum proteins to the nano-fibrous scaffold. A representative result of two independent experiments is shown. (C) Relative intensities of each protein band to serum.

optosis, modulate the activities of cytokines and growth factors, and activate intracellular signaling. ${ }^{12}$ Thus, cell-scaffold (artificial ECM) interactions are one of the most important issues for tissue-engineering applications. There has been very active research on the effects of chemical modification or surface morphology of materials on cell behavior. ${ }^{13,14}$ Certain bioactive peptides such as RGD-modified surfaces of polymer or other materials can enhance cell adhesion in serum-free culture medium. ${ }^{15,16}$ The cell behavior on surfaces with edges, grooves, or other textures is different from cell behavior on smooth surfaces. ${ }^{14,17}$ However, these modifications did not exceed the 2D concept: cells are only attached and interact with a material surface on one side. Considering that the cell in vivo contacts and communicates with ECM in three dimensions, the 3D structure is critical for scaffolds in tissue engineering. Here, we have demonstrated for the first time that the nano-fibrous scaffolding architecture (also having a high porosity and interconnectivity between pores) enhances protein adsorption and selectivity to certain proteins contributing to cell attachment.

We have also shown that the amount of proteins adsorbed to nano-fibrous scaffolds was much greater than that to solid-walled scaffolds. Higher surface-to-

TABLE I

Band Intensities of Proteins Adsorbed to the Solid-Walled and Nano-Fibrous PLLA Scaffolds From Bovine Serum

\begin{tabular}{|c|c|c|c|c|c|c|}
\hline \multirow[b]{2}{*}{ Band No. } & \multirow{2}{*}{$\begin{array}{l}\text { Approximate } \\
\text { Size of Proteins } \\
(\mathrm{kDa})\end{array}$} & \multicolumn{2}{|c|}{ Band Intensity $^{a}$} & \multicolumn{2}{|c|}{$\begin{array}{c}\text { Relative Intensity to } \\
\text { Serum }^{\mathrm{b}}\end{array}$} & \multirow{2}{*}{$\begin{array}{c}\text { Ratio of Nano } \\
\text { to Solid }\end{array}$} \\
\hline & & Solid & Nano & Solid & Nano & \\
\hline 1 & 180 & 0.036 & 0.107 & 0.522 & 1.551 & 3.0 \\
\hline 2 & 150 & 0.041 & 0.118 & 0.336 & 0.967 & 2.9 \\
\hline 3 & 120 & 0.008 & 0.146 & 0.615 & 11.354 & 18.3 \\
\hline 4 & 105 & 0.003 & 0.053 & 0.750 & 13.250 & 17.7 \\
\hline 5 & 90 & 0.015 & 0.086 & 0.789 & 4.526 & 5.7 \\
\hline 6 & 81 & 0.080 & 0.196 & 0.452 & 1.107 & 2.5 \\
\hline 7 & 75 & 0.057 & 0.104 & 0.491 & 0.897 & 1.8 \\
\hline 8 & 70 & 0.443 & 0.983 & 0.453 & 1.004 & 2.2 \\
\hline 9 & 68 & 0.121 & 0.259 & 0.761 & 1.629 & 2.1 \\
\hline 10 & 60 & 0.063 & 0.250 & 0.335 & 1.330 & 4.0 \\
\hline 11 & 55 & 0.152 & 0.257 & 0.338 & 0.571 & 1.7 \\
\hline 12 & 45 & ND & 0.111 & ND & 2.707 & - \\
\hline 13 & 40 & ND & 0.073 & ND & 3.042 & - \\
\hline 14 & 26 & 0.052 & 0.123 & 0.333 & 0.745 & 2.2 \\
\hline 15 & 25 & 0.042 & 0.285 & 0.241 & 1.638 & 2.2 \\
\hline
\end{tabular}

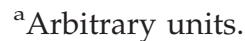

${ }^{\mathrm{b}}$ The relative band intensity to its corresponding band intensity of serum.

ND, not detected. 


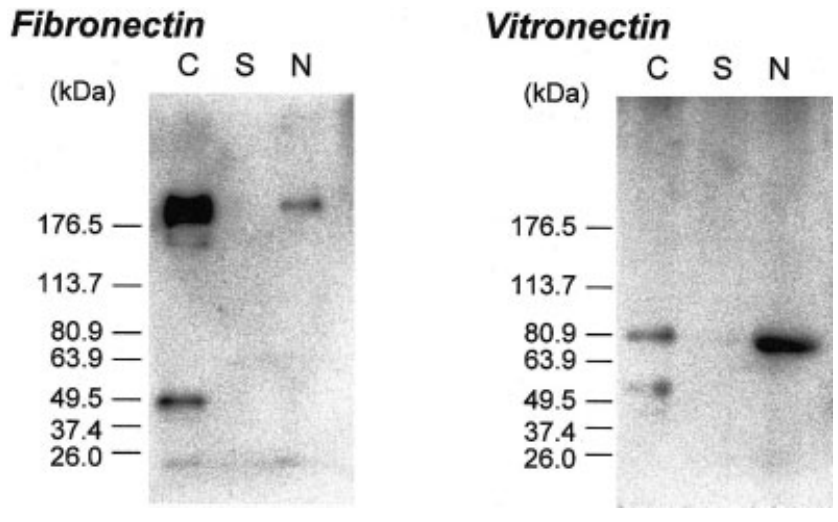

Figure 3. Western blot for fibronectin (left) and vitronectin (right). Lane C, control purified fibronectin $(1 \mu \mathrm{g})$ or vitronectin $(0.5 \mu \mathrm{g})$; lane $S$, adsorbed human serum proteins to the solid-walled scaffold; lane $\mathrm{N}$, adsorbed human serum proteins to the nano-fibrous scaffold.

volume ratio of nano-fibrous scaffolds ${ }^{10}$ may contribute to enhanced protein adsorption. Interestingly, the nano-fibrous scaffolds adsorbed a different profile of proteins from that seen in the solid-walled scaffolds, even though both scaffolds were made from the same PLLA material (Figs. 2 and 4). More specific affinities of certain proteins to the nano-fibrous scaffolds suggest that the nano-fibrous architecture may act as a selective substrate, enhancing cell-ECM interactions. In addition to surface-to-volume ratio, the geometry of nano-fibers, the crystallinity, and orientation of the polymer could affect the affinities of proteins. All these factors possibly work together in enhancing protein adsorption and the specificity to the nano-fibrous scaffolds.

The unique collagen amino acid sequence forms three coiled subunits, which wind around each other

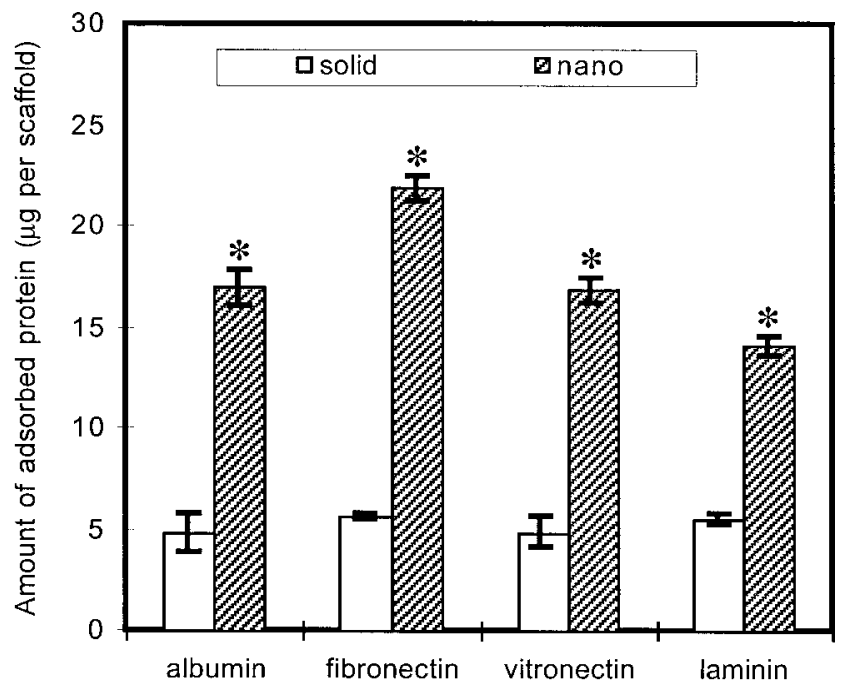

Figure 4. Amounts of adsorbed proteins to the scaffolds. *Significantly different from solid-walled scaffolds, $p<0.05$, $n=4$.

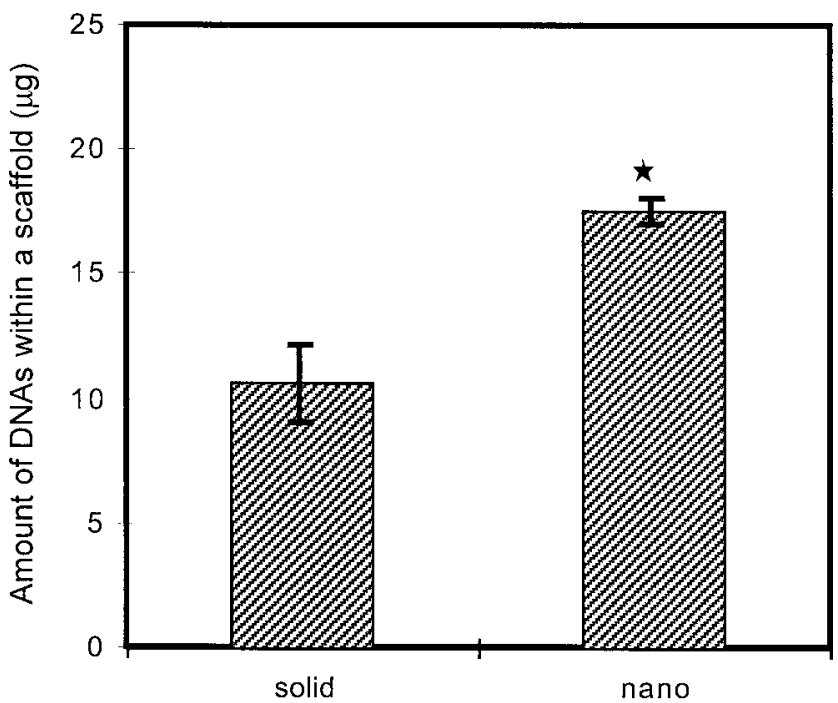

Figure 5. DNA contents within a construct. *Significantly different from solid-walled scaffolds, $p<0.05, n=4$.

in a characteristic right-handed triple helix, forming a collagen molecule. These molecules pack together side-by-side to form fibrils, and are further bundled into collagen fibers varying in diameter from 50 to 500 $\mathrm{nm}$. PLLA has been shown to crystallize into helical structures. ${ }^{18-20}$ The helices existing in the synthetic PLLA nano-fibers may mimic collagen on a molecular level, and may explain in part the protein adsorption specificity and enhanced cell attachment.

Most tissue-derived cells are anchorage dependent and require attachment to a solid substrate for viability and growth. For this reason, the initial events that occur when a cell approaches a substrate are of fundamental interest. We showed that nano-fibrous scaffolds enhanced cell attachment 1.7-fold. The histology revealed that the cells adhered on the spherical macropore walls in the scaffolds (data not shown). This result indicates that both scaffolds, solid-walled and nano-fibrous, appear to have similar capacity at the macro and micro scales for cell accommodation even though the nano-fibrous scaffolds have higher surface area at the nanometer scale. Thus, it appears that the nano-fibrous scaffolds provide a more favorable environment for cells because of the nano-scaled features. As mentioned earlier, the cell behaviors appear to be secondary to adsorption of cell attachment proteins. The nano-fibrous architecture could increase the cell attachment to the scaffolds through better protein adsorption, including fibronectin and vitronectin, at least in part. In addition, nano-fibrous architecture could alter the mode of anchorage. Filopodia of the cells were reported to direct to certain particulate structure. $^{21}$ The nano-fibrous architecture could allow filopodia to anchor more tightly, and this mode of anchorage could also contribute to the adhesion strength to the nano-fibrous scaffolds. 


\section{CONCLUSIONS}

The newly developed nano-fibrous scaffolds adsorbed greater amounts and a more specific profile of proteins than the solid scaffolds. The nano-fibrous scaffolds also enhanced cell attachment. These findings suggest that nano-fibrous architecture in scaffolds provide a more favorable microenvironment for the cells, and support our hypothesis that nano-structured synthetic scaffolding could mimic the cell-ECM microenvironment.

The authors acknowledge funding from DuPont Young Professor Award, University of Michigan (Nano Materials Initiative, and Center for Biomedical Engineering Research), the Whitaker Foundation, and Korea Science \& Engineering Foundation (postdoctoral fellowship to K. M. Woo).

\section{References}

1. Langer R, Vacanti JP. Tissue engineering. Science 1993;260: 920-926.

2. Nerem RM. The challenge of imitating nature. In: Lanza RP, Langer R, Vacanti J, editors. Principles of tissue engineering. San Diego: Academic Press; 2000. p 9-15.

3. Alberts B, Johnson A, Lewis J, Raff M, Roberts K, Walter P. Molecular biology of the cell. 4th ed. New York: Garland Science; 2002.

4. Pachence JM. Collagen-based devices for soft tissue repair. J Biomed Mater Res 1996;33:35-40.

5. Anselme K, Bacques C, Charriere G, Hartmann DJ, Herbage D, Garrone R. Tissue reaction to subcutaneous implantation of a collagen sponge: A histological, ultrastructural, and immunological study. J Biomed Mater Res 1990;24:689-703.

6. Ma PX, Zhang R. Synthetic nano-scale fibrous extracellular matrix. J Biomed Mater Res 1999;46:60-72.

7. Elsdale T, Bard J. Collagen substrata for studies on cell behavior. J Cell Biol 1972;54:626-637.
8. Strom SC, Michalopoulos G. Collagen as a substrate for cell growth and differentiation. Methods Enzymol 1982;82:544-555.

9. Grinnell F, Bennett MH. Ultrastructural studies of cell-collagen interactions. Methods Enzymol 1982;82:535-544.

10. Zhang R, Ma PX. Synthetic nano-fibrillar extracellular matrices with predesigned macroporous architectures. J Biomed Mater Res 2000;52:430-438.

11. Ma PX, Choi J. Biodegradable polymer scaffolds with welldefined interconnected spherical pore network. Tissue Eng 2001;7:23-33.

12. Martins-Green M. Dynamics of cell-ECM interaction. In: Lanza RP, Langer R, Vacanti J, editors. Principles of tissue engineering. San Diego: Academic Press; 2000. p 33-55.

13. Luck M, Paulke BR, Schroder W, Blunk T, Muller RH. Analysis of plasma protein adsorption on polymeric nanoparticles with different surface characteristics. J Biomed Mater Res 1998;39: $478-485$.

14. Saltzman WM. Cell interactions with polymers. In: Lanza RP, Langer R, Vacanti J, editors. Principles of tissue engineering. San Diego: Academic Press; 2000. p 221-235.

15. Hubbell JA, Massia SP, Drumheller PD. Surface-grafted cellbinding peptides in tissue engineering of the vascular graft. Ann NY Acad Sci 1992;665:253-258.

16. Lin HB, Sun W, Mosher DF, Garcia-Echeverria C, Schaufelberger K, Lelkes PI, Cooper SL. Synthesis, surface, and celladhesion properties of polyurethanes containing covalently grafted RGD-peptides. J Biomed Mater Res 1994;28:329-342.

17. Matsuzaka K, Walboomers F, de Ruijter A, Jansen JA. Effect of microgrooved poly-L-lactic (PLA) surfaces on proliferation, cytoskeletal organization, and mineralized matrix formation of rat bone marrow cells. Clin Oral Implant Res 2000;11:325-333.

18. Brizzolara D, Cantow HJ, Diederichs K, Keller E, Domb A. Mechanism of the stereocomplex formation between enantiomeric poly(lactide)s. Macromolecules 1996;29:191-197.

19. Hoogsteen W, Postema AR, Pennings AJ, ten Brinke G, Zugenmaier P. Crystal structure, conformation, and morphology of solution-spun poly(L-lactide) fibers. Macromolecules 1990;23: 634-642.

20. Eling B, Gogolewski S, Pennings AJ. Biodegradable materials of poly(L-lactic acid). I. Melt-spun and solution-spun fibres. Polymer 1982;23:1587-1593.

21. Filmon R, Basle MF, Atmani H, Chappard D. Adherence of osteoblast-like cells on calcospherites developed on a biomaterial combining poly(2-hydroxyethyl)methacrylate and alkaline phosphatase. Bone 2002;30:152-158. 